\title{
MICROWAVE TREATMENT OF HUMAN MILK TO PREVENT TRANSMISSION OF CHAGAS DISEASE
}

\begin{abstract}
SUMMARY
It is recognized that breast feeding is an alternative means of transmission of Chagas disease. However, thermal treatment of milk can prevent this occurrence. As domestic microwave ovens are becoming commonplace, the efficacy of microwave thermal treatment in inactivating Trypanosoma cruzi trypomastigotes in human milk was tested. Human milk samples infected with T. cruzi trypomastigotes (Y strain) from laboratory-infected mice, were heated to $63{ }^{\circ} \mathrm{C}$ in a domestic microwave oven $(2450 \mathrm{MHz}, 700 \mathrm{~W}$ ). Microscopical and serological examinations demonstrated that none of the animals inoculated orally or intraperitoneally with infected milk which had been treated, got the infection, while those inoculated with untreated, infected milk, became infected. It was concluded that the simple treatment prescribed, which can easily be done at home, was effective in inactivating $T$. cruzi trypomastigotes contained in human milk.
\end{abstract}

KEYWORDS: Trypanosoma cruzi; Microwave thermal treatment.

On the basis of observational and experimental investigation, it has been pointed out that there is little likelihood of Trypanosoma cruzi infection being transmitted through breastfeeding. Yet, in view of the serious clinical and epidemiological consequences of Chagas disease, this alternative means of transmission has been a matter of considerable concern $^{1,2}$.Pasteurization, the well-known process for inactivating most pathogens found in milk, is demonstrably effective against $T$. cruzi ${ }^{2}$. However, this technique can be time-consuming and pose many problems to those trying to do it at home. Microwaves have been currently used with increasing frequency for the pasteurization and sterilization of foodstuffs. The availability of microwave ovens in most households ${ }^{3}$ suggests the use of such domestic appliances as a simple and rapid way to produce the thermal effect upon which pasteurization is based. An experiment was set up, along the same lines as a previous one ${ }^{2}$, to evaluate the efficacy of microwave treatment of human milk in inactivating $T$. cruzi trypomastigotes.

A model MS-74ML LG (700 W; 2,450 MHz) microwave oven was used. Five 10-mL aliquots from a 50-mL sample of human milk, from a healthy donor, were distributed among test tubes numbered 1 to 5 . This sample had been previously kept at the temperature of $-18^{\circ} \mathrm{C}$. To tubes 1 to 4, respectively $2500,5000,10000$, and $2500 \mathrm{~T}$. cruzi, trypomastigotes ( $\mathrm{Y}$ strain) per $\mathrm{mL}$, from laboratory-infected BALB/c mice, were added. No infecting material was added to tube 5. Tubes 1 to
3 were put into a beaker filled with water to the $500 \mathrm{~mL}$ mark. The beaker with its contents was put into the oven, the time set for seven minutes and the power to $40 \%$. The temperature of the contents of the tubes, measured after the end of the process with a mercury thermometer, was $63{ }^{\circ} \mathrm{C}$. The immersion of the tubes in water and the protracted duration of the treatment aim at improving the uniformity of heating, an important factor in the process. The tubes were then cooled in a refrigerator. No thermal treatment was applied to samples 4 and 5 (no infecting material had been added to sample 5). Ten batches of mice were supplied by the Laboratory Animal Facility Center, Faculty of Medicine of the University of São Paulo. They were marked A to J: batches A to H, composed of ten mice; I and J, of five mice each. Infected and noninfected milk samples were administered (orally and intraperitoneally) to the animals, as described in Table 1.

Starting from the fifth day of administration, fresh samples of peripheral blood taken from each mouse were examined $(400 \times$ magnification $)$ at 3 day intervals during 60 days. After that period, further blood samples were taken for serological (ELISA) tests. All animals which had received thermally treated, either infected or uninfected milk, had negative parasitological and serological test results. On the other hand, the animals which received infected, non-treated milk, had both tests positive. It was concluded that microwave treatment of human milk, done as described, is effective in inactivating suspended $T$. cruzi trypomastigotes. 
Table 1

Inoculation of experimental animals acording to conditions described

\begin{tabular}{ccclc}
\hline Batch & $\begin{array}{c}\text { Number } \\
\text { of animals }\end{array}$ & $\begin{array}{c}\text { Volume } \\
(\mathrm{mL})\end{array}$ & Inoculation & Parasites/mL \\
\hline A & 10 & 0.1 & Oral & 2500 \\
B & 10 & 0.5 & Intraperitoneal & 2500 \\
C & 10 & 0.1 & Oral & 5000 \\
D & 10 & 0.5 & Intraperitoneal & 5000 \\
E & 10 & 0.1 & Oral & 10000 \\
F & 10 & 0.5 & Intraperitoneal & 10000 \\
G & 10 & 0.1 & Oral & $2500^{*}$ \\
H & 10 & 0.5 & Intraperitoneal & $2500^{*}$ \\
I & 5 & 0.1 & Oral & 0 \\
J & 5 & 0.5 & Intraperitoneal & 0 \\
\hline
\end{tabular}

* No thermal treatment

The process can be easily done at home, preferably with an oven equipped with a rotating plate. Two heat-resistant glass containers should be used, a smaller one to be filled with milk and put inside the larger one, to be filled with water. To find out the amount of radiation necessary to heat the volume of milk in the inner container to the desired temperature, try different settings of the power control, keeping the time setting constant, until the desired temperature (to be measured with an immersion thermometer after the end of the process) is reached. The volumes of the liquids remaining constant, the same power and time settings will produce the same effect.

\section{RESUMO}

\section{Tratamento do leite humano pelo microondas para prevenir a transmissão de doença de Chagas}

A amamentação é reconhecidamente um modo alternativo de transmissão da doença de Chagas. Entretanto, o tratamento térmico do leite pode evitar tal acidente. Por ser atualmente comum o uso doméstico de fornos de microondas, projetou-se um experimento para avaliar a eficácia do tratamento térmico do leite por microondas na inativação de formas de Trypanosoma cruzi contidas no leite materno. Acrescentaramse, a amostras de leite humano, tripomastigotas de T. cruzi (cepa Y) provenientes de camundongos infectados em laboratório. Essas amostras foram aquecidas a $63{ }^{\circ} \mathrm{C}$ (sete minutos, $45 \%$ de potência) em forno de microondas doméstico (2 $450 \mathrm{MHz}, 700 \mathrm{~W}$ ). Exames microscópicos e sorológicos dos animais inoculados, por via oral ou intraperitoneal, com leite infectado e tratado, foram negativos. Os resultados dos inoculados com leite infectado e não tratado foram positivos. Concluiu-se que este é um processo simples e eficaz para inativar tripomastigotas contidos em leite, podendo facilmente ser executado em ambiente doméstico.

\section{ACKNOWLEDGMENTS}

The authors are indebted to Dr. Roseana B. Cruz, and Auxiliary Nurse Claudia Rosolia, of Hospital do Servidor Público Estadual "Francisco Morato de Oliveira", for their kind help in procuring the human milk sample used in this experiment.

\section{REFERENCES}

1. CHIEFFI, P.P. \& AMATO NETO, V., org. - Prevenção referente às modalidades alternativas de transmissão do Trypanosoma cruzi. São Paulo, Instituto de Medicina Tropical de São Paulo, 2000.

2. FERREIRA, C.S.; MARTINHO, P.C.; AMATO NETO, V. \& CRUZ, R.R.B. Pasteurization of human milk to prevent transmission of Chagas disease. Rev. Inst. Med. trop. S. Paulo, 43: 161-162, 2001.

3. Microwave and Radio Frequency Processing. U.S. Food and Drug Administration/Center for Food Safety and Applied Nutrition, June 2, 2000. http://vm.cfsan.fda.gov/ comm/ ift-micr.html

Receiced: 19 November 2002 Accepted: 6 December 2002 